Prof and Head of Avian and Rabbit.

Medicine Dept Jac.of Vet. Med. Zagazig

\title{
VIRAL AGENTS ASSOCIATED WITH RETARDED GROWTH IN BROILER CHICKENS
}

(With 6 Tables)

By

A.M.A. HEGAZY; A.A. BAYOUMIE*; O.A. SAMAHA **
*Technical Manager of NLQP-Sharkia, ** Goves Zagazig

(Received at 20/4/2009)

المسببات الفيروسية المرتبطة بتأخر النمو فى بارىى التسمين

أحد الصادق محد حجازى ، هشام أحد عبل البليع ، أسامة أحمد سعاحة

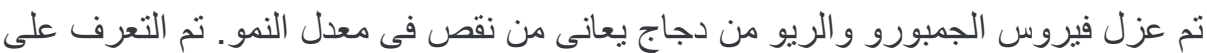

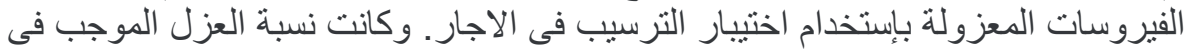

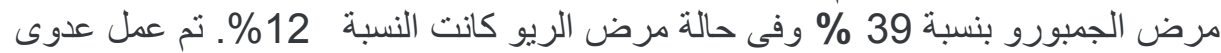

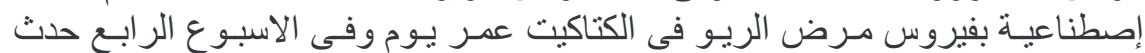

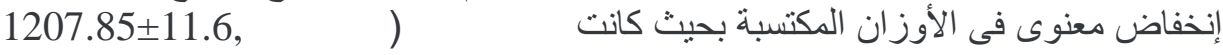

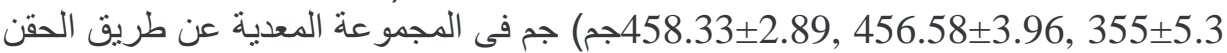

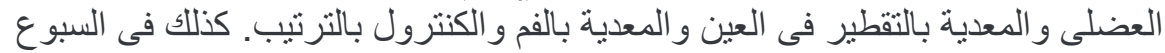

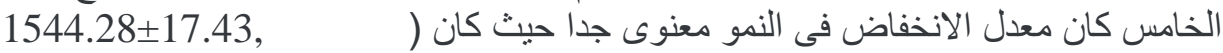

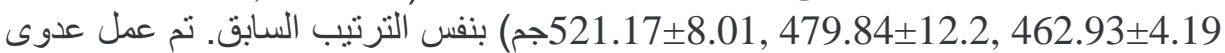

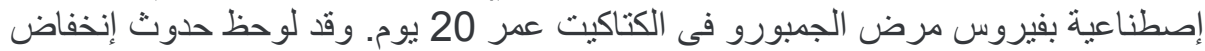

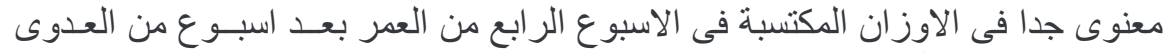

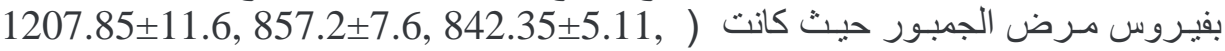

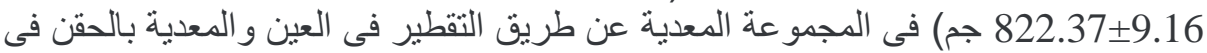

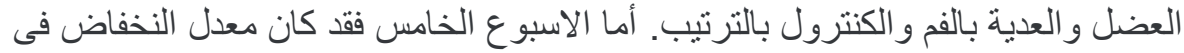

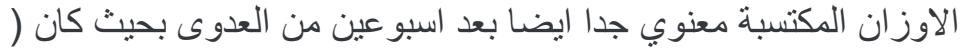

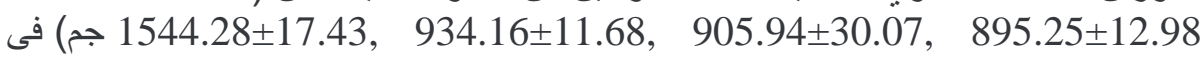
المجمو عة المعدية عن طريق الحقن العضلى و المعدية بالتقطير فى العين و المعدية بالفم

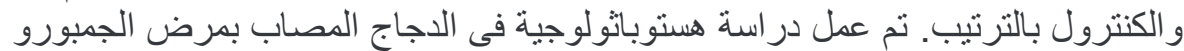

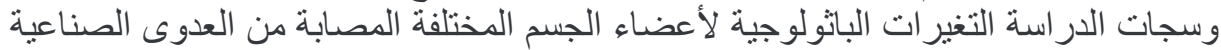

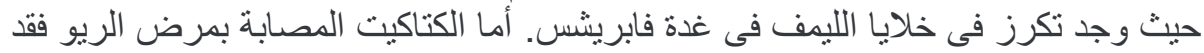

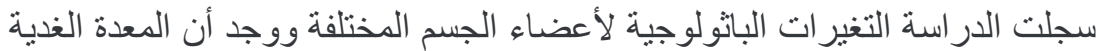
بها تجمعات من كر ات الدم البيضاء و الهيتيروفيل وخلايا الليمف. (proventriculus)

\section{SUMMARY}


In the present study Reoviruses and IBDV were isolated from clinical cases of chickens showing retarded growth. The Percent of virus isolation was $12.1 \%$ for Reoviruses and $39.6 \%$ for IBDV. The titer of the selected Reov isolate was $10^{4} .{ }^{8}$ EIDSO/0.2ml while it was $10^{4} .{ }^{2} \mathrm{EIDSO} / 0.2 \mathrm{ml}$ for the selected IBDV isolate. Pathogenecitity trials with the isolated viral agents revealed retarded growth with variable degrees where the decrease in body weight ranged from $66.3 \_70 \%$, and $40 \_42 \%$ after Reovirus and IBDV infection respectively depending on the inoculation route

Key words:

\section{INTRODUCTION}

Malabsorption syndrome "MAS" is a widely spreaded problem in poultry industry with severe economic consequences caused by an enteric pathogen or by a combination of pathogens, mainly viruses (Zekarias et al., 2002); Bayoumie 2004). The exact causative agent of "MAS" was the subject of great argue due to the isolation of a variety of agent s from the clinical cases of "MAS" (Page et al., 1982; Meferran et al. (1983); Goodwin et al., 1985; Decaesstecker et al., 1986; Mcnulty et al. (1990)

Avian Reoviruses was proven to be a causative agent for "MAS" and the disease was successfully reproduced (Bayoumie, 2004). Recently IBDV isolates evolved as a viruses that can cause or contribute in infectious proventriculitis causing retarded growth (Skeels. et al., 1995); Huff. et al., 1997; Giambrane 2002a; Giambrane 2002b)

The present work aim to isolate and identify the viral agents from clinical cases of retarded growth, and to study their pathogenicity in chickens and their effect on performance parameters beside histological examination

\section{MATERIALS and METHODS}

\section{Materials}

\section{1- Specimens}

Samples from one hundred and seventy chickens suffering growth retardation were collected from field cases for virus isolation trails. Proventriculus, intestine and pancreas were used for preparation of intestinal homogenate (Kouwenhoven et al., 1988) for Reoviruses Isolation attempts, while bursae, livers and spleens were used for IBVD isolation attempts 


\section{2- Day old chickens}

One hundred and seventy day old broiler chicks "cobb" obtained from Cairo poultry company (CPC) were used in experimental trials. Birds were reared in floor pens under strict hygienic condition

\section{3- Ration}

starter broiler ration "3000 k cal energy, $21 \%$ protein and $3.6 \%$ fat" obtained from "EL eslamya company"

\section{4- Embryonated chicken eggs (ECE)}

9 - 11 day old (ECE) from native flocks were used for virus isolation, propagation and titration.

\section{5- Reoviruses and IBDV antigens and antisera}

Standard Reoviruses/ IBDV antigen and antisera were obtained from Animal Health Res. Inst - Dokki - Giza Egypt.

\section{Methods}

\section{1- Preparation of specimen's for viruses isolation}

Collected tissues were aseptically grounded, 1:10 dilution was prepared in phosphate buffer saline (PBS1.the suspension was centrifuged at $30002 \mathrm{pm}$ for $15 \mathrm{~m}$ in. The supernatant was membrane filtered then used for ECE inoculation as described by Kouwenhoven et al. (1988) and Senne (2008)

\section{2- Agar gel precipitation test (AGPT)}

The test was performed as described by Thayer and Beard (2008).

\section{3-Viral titration}

Viral titration was performed in ECE. The embryo infective dose 50 was calculated according to Read and Munch (1938)

\section{4-Experimental design}

Table (1) shows the distribution of experimental birds Used in the present study.

\section{Table l: Experimental design}


Assiut Vet. Med. J. Vol. 55 No. 122 July 2009

\begin{tabular}{|c|c|c|c|c|c|c|c|c|c|}
\hline \multirow{2}{*}{$\begin{array}{c}\text { Experi } \\
\text { ment }\end{array}$} & \multirow{2}{*}{$\begin{array}{l}\text { Number } \\
\text { Of bird/ } \\
\text { Group }\end{array}$} & \multirow{2}{*}{$\begin{array}{l}\text { Age } \\
\text { of } \\
\text { birds }\end{array}$} & \multirow{2}{*}{$\begin{array}{l}\text { Sub } \\
\text { group }\end{array}$} & \multirow{2}{*}{$\begin{array}{l}\text { Number } \\
\text { of bird/ } \\
\text { subgroup }\end{array}$} & \multicolumn{4}{|c|}{ Infection } & \multirow[t]{2}{*}{ Serum samples } \\
\hline & & & & & Virus & Dose & Route & Age & \\
\hline \multirow[t]{2}{*}{1} & \multirow[t]{2}{*}{60} & \multirow[t]{2}{*}{$\begin{array}{l}20 \text { day } \\
\text { old }\end{array}$} & $\begin{array}{l}\text { A } \\
\text { B }\end{array}$ & $\begin{array}{l}20 \\
20\end{array}$ & \multirow[t]{2}{*}{ IBDV } & \multirow[t]{2}{*}{$10^{4.2 / 0.2 \mathrm{ml}}$} & $\begin{array}{c}\mathrm{I} / \mathrm{M} \\
\text { Orally }\end{array}$ & \multirow[t]{2}{*}{20 day of age } & \multirow[t]{2}{*}{$\begin{array}{c}28,3 \mathrm{~S}, 42 \text { day } \\
\text { of age }\end{array}$} \\
\hline & & & $\mathrm{C}$ & 20 & & & Eye drop & & \\
\hline \multirow[t]{3}{*}{2} & \multirow[t]{3}{*}{60} & \multirow[t]{3}{*}{ Day old } & A & 20 & \multirow{3}{*}{$\begin{array}{l}\text { Reo } \\
\text { virus }\end{array}$} & \multirow[t]{3}{*}{$10^{4.8 / 0.2 \mathrm{ml}}$} & $\mathrm{I} / \mathrm{M}$ & \multirow[t]{3}{*}{ One day old } & \multirow[t]{3}{*}{$7,14,21$, day of } \\
\hline & & & B & 20 & & & Orally & & \\
\hline & & & $\mathrm{C}$ & 20 & & & Eye drop & & \\
\hline 3 & 50 & - & \multicolumn{7}{|c|}{ C-ve(negative control) } \\
\hline
\end{tabular}

\section{5- Histolopathology}

Specimens were fixed in $10 \%$ formalin, $5 \mu$ paraffin section were prepared and stained with $\mathrm{H} \& \mathrm{E}$, as described by Bancroft and steven (1996), and was examined by light microscope

\section{6- Performance parameters}

The body weight (BWT), Body gain (BG), Feed intake (FI) and feed conversion rate $(\mathrm{FeR})$ were used as indicators for performance parameters

\section{7- Statistical analysis}

Obtained data were statistically analyzed according to Tamhane and Dunlop (2000)

\section{RESULTS}

\section{1- Virus isolation and identification}

Harvested chorioallantoic membranes (CAM) of inoculated ECE with suspected materials were grounded, examined with AGPT for IBDV. and Reoviruses. The total positive samples for IBDV were 39.6\% while it was $12.1 \%$ for Reoviruses. One isolated sample from each viral group was titrated.

\section{2- Virus titration}


The titer of selected Reovirus was $10^{4} .{ }^{8}$ EIOSO $10.2 \mathrm{ml}$ while the titer of the selected IBOV was 104.2 EIOSOIO.2ml

\section{3- Results of experimental infection with Reovirus isolate and performance parameter}

The clinical symptoms, P.M. lesions post inoculation are shown in the Table 2. The mortality post inoculation varied according to the route of inoculation, it was $20 \%$ in subgroup (A) inoculated via $11 \mathrm{M}$ route, and $10 \%$ in subgroup (B) inoculated via oral route, while it was $5 \%$ in subgroup (c) inoculated via eye drops. The performance parameters at 4 weeks of age for subgroup (A) inoculated via 11M route showed the lowest Mean body weight gain $355 \pm 5.3 \mathrm{gm}$ followed by subgroups $\mathrm{C}$ and $\mathrm{B}$ (Table 3 ). There was also a significant difference in conversion rate when compared with control $(5.37 \pm 0.076,4.19 \pm 0.029$ and $4.26 \pm 0.47$ in subgroup A,B and C respectively (Table 3), while the performance parameters at $5^{\text {th }}$ week revealed that chickens of subgroup(A) infected I/M showed the lowest Mean body weight gain followed by subgroup $\mathrm{C}$ and $\mathrm{B}$. The difference in feed conversion was significant when compared with control as it was $6.9 \pm 0.42,6.09 \pm 0.11$ and 6.65 \pm .1 ) in subgroup A,b, and C respectively (Table 4).

Table 2: Pathogenicity of Reo virus, and IBVD infection in chickens:

\begin{tabular}{|c|c|c|c|c|c|c|c|}
\hline Group & \multicolumn{3}{|c|}{1 (Reo) } & \multicolumn{3}{|c|}{$2(180)$} & Control \\
\hline Subgroup & A & B & $\mathrm{C}$ & A & B & $\mathrm{C}$ & \\
\hline Birds No & 20 & 20 & 20 & 20 & 20 & 20 & 50 \\
\hline Route & $\mathrm{I} / \mathrm{m}$ & Orally & Eye drop & $\mathrm{I} / \mathrm{m}$ & Orally & Eye drop & \\
\hline Mortality & $4(20 \%)$ & $2(10 \%)$ & $1(5 \%)$ & $6(30 \%)$ & $3(15 \%)$ & $2(10 \%)$ & - \\
\hline Survivors & 16 & 18 & 19 & 14 & 17 & 18 & 50 \\
\hline $\begin{array}{l}\text { 1-clinical } \\
\text { Signs }\end{array}$ & \multicolumn{3}{|c|}{ Vent pasting \& trembling } & \multicolumn{3}{|c|}{$\begin{array}{l}\text { Perfuse watery yellowish diarrhea and } \\
\text { Severe body weight variation }\end{array}$} & \multirow[t]{2}{*}{$\begin{array}{l}\text { No } \\
\text { symptoms }\end{array}$} \\
\hline $2-\mathrm{p} / \mathrm{m}$ & \multicolumn{3}{|c|}{$\begin{array}{l}\text { Proventriculitis ,pale intestine } \\
\text { Filled with gases \&emaciation }\end{array}$} & \multicolumn{3}{|c|}{$\begin{array}{l}\text { Hemorrhages on thigh ,swollen bursae } \\
\text { And congested kidneys }\end{array}$} & \\
\hline
\end{tabular}

Table 3: The effect of Reo virus infection on body performance at 28 
day old.

\begin{tabular}{|c|c|c|c|c|c|c|}
\hline Group & Subgroup & Route & Body weight & Body gain & Feed in take & $\begin{array}{c}\text { Feed conversion } \\
\text { rate }\end{array}$ \\
\hline \multicolumn{2}{|c|}{ Cove } & & $1245.56 \pm 9.18 \mathrm{a}$ & $1207.85 \pm 11.6 \mathrm{a}$ & $1925.71 \pm 12.32 \mathrm{a}$ & $1.58 \pm 0.02 \mathrm{c}$ \\
\hline \multirow{2}{*}{$\mathbf{1}$} & A & $11 \mathrm{M}$ & $393.75 \pm 5.49 \mathrm{c}$ & $355 \pm 5.3 \mathrm{c}$ & $1915.62 \pm 5.98 \mathrm{a}$ & $5.37 \pm 0.076 \mathrm{a}$ \\
\cline { 2 - 7 } & B & orally & $498.33 \pm 2.89 \mathrm{~b}$ & $458.33 \pm 2.89 \mathrm{~b}$ & $1928.89 \pm 7.2 \mathrm{a}$ & $4.19 \pm 0.029 \mathrm{~b}$ \\
\cline { 2 - 7 } & C & Eye drop & $496.58 \pm 3.96 \mathrm{~b}$ & $456.58 \pm 3.96 \mathrm{~b}$ & $1935.26 \pm 7.39 \mathrm{a}$ & $4.26 \pm 0.047 \mathrm{~b}$ \\
\hline
\end{tabular}

Table 4: The effect of Reo virus infection on body performance at 35 day old.

\begin{tabular}{|c|c|c|c|c|c|c|}
\hline Group I & Subgroup & Route & Body weight & Body gain & Feed in take & Feed conversion rate \\
\hline & C-ve & & $1594.44 \pm 14.54 \mathrm{a}$ & $1544.28 \pm 17.43 a$ & $3142.85 \pm 38.46 \mathrm{a}$ & $1.99 \pm 0.029 \mathrm{c}$ \\
\hline \multirow[t]{3}{*}{1} & A & $1 / \mathrm{M}$ & $502.93 \pm 4.2 \mathrm{c}$ & $462.93 \pm 4.19 c$ & $3203.33 \pm 10.3 \mathrm{a}$ & $6.9 \pm 0.072 \mathrm{a}$ \\
\hline & B & Orally & $561.18 \pm 8.01 \mathrm{~b}$ & $521.17 \pm 8.01 \mathrm{~b}$ & $3179.4 \pm 16.64 a$ & $6.09 \pm 0.11 \mathrm{~b}$ \\
\hline & $\mathrm{C}$ & Eye drop & $519.84 \pm 12.19 \mathrm{c}$ & $479.84 \pm 12.2 \mathrm{c}$ & $3168.95 \pm 17.17 \mathrm{a}$ & $6.65 \pm 0.18 \mathrm{a}$ \\
\hline
\end{tabular}

\section{4- Results of experimental infection with IBDV isolate and performance parameters}

The clinical symptoms, P.M. lesions, post inoculation with IBDV, are shown in (Table 2) mortality also varied in the different experimental groups. The mortality was $30 \%$ in subgroup (A) inoculated $1 / \mathrm{M}$ and $15 \%$ in subgroup (B) and $10 \%$ in subgroup (C) inoculated orally or via eye drops. Inoculated birds showed characteristics signs and lesions of IBDV. The observed performance at 4 week of age showed that group (C) inoculated via eye drops showed the lowest mean body weight gain followed by subgroup A then B (Table 5) The performance parameters at $3 \mathrm{~S}$ day showed that subgroup injected 1/M showed the lowest mean body weight gain followed by group ( B) and ( C) (Table 5, 6)

Table 5: The effect of IBD virus infection on body performance at 28 
day old:

\begin{tabular}{|c|c|c|c|c|c|c|c|}
\hline Group & I & Subgroup & Route & Body weight & Body gain & Feed in take & Feed conversion rate \\
\hline \multicolumn{4}{|c|}{ C-ve } & $1245.56 \pm 9.18 \mathrm{a}$ & $1207.85 \pm 11.6 \mathrm{a}$ & $1925.7 \pm 12.32 \mathrm{a}$ & $1.58 \pm 0.02 \mathrm{c}$ \\
\hline \multirow[t]{3}{*}{2} & & A & $1 / \mathrm{M}$ & $882.35 \pm 5.11 \mathrm{~b}$ & $842.35 \pm 5.11 b c$ & $1928.23 \pm 6.7 \mathrm{a}$ & $2.28 \pm 0.018 \mathrm{ab}$ \\
\hline & & B & Orally & $895.63 \pm 7.89 b$ & $857.2 \pm 7.6 \mathrm{~b}$ & $1923.68 \pm 6.03 \mathrm{a}$ & $2.23 \pm 0.023 \mathrm{~b}$ \\
\hline & & $\mathrm{C}$ & Eye drop & $860.26 \pm 5.62 \mathrm{c}$ & $822.37 \pm 9.16 \mathrm{c}$ & $1920.52 \pm 7.02 \mathrm{ba}$ & $2.34 \pm 0.018 \mathrm{a}$ \\
\hline
\end{tabular}

Means with different superscripts are significant at $\mathrm{p} \leq 0.05$.

Chicks were infected at 20 day old

C-ve: negative control

Table 6: The effect of IBD virus infection on body performance at 35 day old:

\begin{tabular}{|c|cc|c|c|c|c|}
\hline Group & Subgroup - Route & Body weight & Body gain & Feed in take & Feed conversion rate \\
\hline \multicolumn{2}{|c|}{ C-ve } & & $1594.44 \pm 14.54 \mathrm{a}$ & $1544.28 \pm 17.43 \mathrm{a}$ & $3142.85 \pm 38.46 \mathrm{a}$ & $1.99 \pm 0.023 \mathrm{~b}$ \\
\hline \multirow{2}{*}{2} & A & $1 / \mathrm{M}$ & $940.87 \pm 16 \mathrm{~b}$ & $895.25 \pm 12.98 \mathrm{~b}$ & $3184.37 \pm 16.27 \mathrm{a}$ & $3.55 \pm 0.058 \mathrm{a}$ \\
\cline { 2 - 7 } & B & Orally & $972.61 \pm 9.8 \mathrm{~b}$ & $905.94 \pm 30.07 \mathrm{~b}$ & $3144.44 \pm 18.47 \mathrm{a}$ & $3.42 \pm 0.047 \mathrm{a}$ \\
\cline { 2 - 7 } & C & Eye drop & $974.16 \pm 11.69 \mathrm{~b}$ & $934.16 \pm 11.68 \mathrm{~b}$ & $3186.8 \pm 17.45 \mathrm{a}$ & $3.4 \pm 0.04 \mathrm{a}$ \\
\hline
\end{tabular}

Means with different superscripts are significant at $\mathrm{p} \leq 0.05$.

Chicks were infected at 20 day old

C-ve: negative control

\section{4- Results pf histopathological examination}

The bursal lymphoid follicles of experimentally infected birds with IBDV showed lymphoid necrosis particularly in the medullary zone and was replaced by eosinophilic necrotic debris or became atrophied and shrunken together with vesicle formation in its covering epithelium. Lymphocytes showed pyknosis and karyorrhexis with hyperplasia of reticulo endothelial cells. Intense heterophil in the inter follicular tissues and within the cavities of some cystic follicles and fibroplasia was observed. Moreover, edema in interfolicular and subepithelial tissues with hyperemic capillaries were seen beside hyperplasia of epithelial covering. The spleenic white pulps revealed intense lymphoid depletion and necrosis particularly in the germinal follicles and periarteriolar lymphoid sheath. Hyperplasic reticuloendothelial cells could be seen in the center of some white pulps around the adenoid sheath artery. The hepatic cells revealed 
degenerative changes with peri vascular mononuclear cell infiltration.

The proventricular submucosa from birds experimentally infected with REOV revealed inter glandular edema accompanied by leukocytic aggregate mainly heterophils and lymphocytes., Other cases, showed disseminated leukocytic infiltration accompanied with degenerated and necrotic changes in the compound glands of the sub mucosa. The mucosa was edematous and infiltrated with leukocyte. The pancreas, showed Interstitial and perivascular leukocytic infiltration and mild lymphocytes infiltration was seen among pancreatic acini. The intestinal villi of the small intestine reduced in length and size with partial desquamation of their lining epithelium, the tips of the villi become rounded and thickened due to lukocytic infiltration in mucosal lamina pro pia and edema

\section{DISCUSSION}

Growth retardation is considered one of the most important problems facing poultry industry. Trials for virus isolation by inoculation of suspected samples in embroynated chicken eggs, and identification using AGPT revealed that the incidence of Reo virus was $12.1 \%$ in examined samples. Similar results were recorded by Reece et al. (1984) who reported that the incidence of runting varied from I to $20 \%$ and most of these birds were culled at the time of slaughter. While the rate of IBO viruses in collected samples were $39.6 \%$. These results were nearly similar to that observed by Islam and Samad (2003), and Zeleke et al. (2005), who reported that the mortality rate of IBO in different poultry houses ranged from $45-50 \%$.

The effect of reo virus infection in one day old chicks showed mortality rate ranged from $5-20 \%$. These finding agreed with those mentioned by Rosenberger et al. 1989) who reported an outbreak in broilers characterized by serious mortality (10-18\%) over a period of few days in chickens less than 14 day $0 \mathrm{I}$ d. Chicks died post inoculation showed vent pasting, and trembling, Reece 1997). Postmortem examination revealed emaciated anemic carcass, pale intestine, filled with gases, enteritis, proventriculitis, and paleness of visceral organs. These findings were similar to Chooi and Chalan (1985); and Wood et al. (1997), ayoumie 2004) eported similar symptoms and P.M. lesions after experimental infection with reov but mortality was 5-10\%

After 28 day of infection revealed significant decrease in body gain (BG) especially $11 \mathrm{M}$ infected groups $355 \pm 5.3 \mathrm{gm}$ when compared 
with intraocular and orally infected groups and control (456.58 \pm 3.96 , $458.33 \pm 2.89 \mathrm{gm}$ and $1207.85 \pm 11.6 \mathrm{gm}$ respectively). While no changes in feed intake in all groups. Significant decrease in FCR observed in all groups when compared with control group, FCR was $35.37 \pm 0.076$, $4.19 \pm 0.029,4.26 \pm 0.047, \%$ and $1.58 \pm 0.02 \%$ ) in all groups, while after 35 day of infection revealed very highly significant decrease in body gain (BG) especially $1 / \mathrm{M}$ infected groups $462.93 \pm 4.19 \mathrm{gm}$ when compared with intraocular and orally infected groups and control $(479.84 \pm 12.2,521.17 \pm 8.01 \mathrm{gm}$ and $1544.28 \pm 17.43 \mathrm{gm}$ respectively). While no changes in feed intake in all groups. Very highly significant decrease in FCR observed in all groups when compared with control group, FCR was $6.9 \pm 0.072,6.09 \pm 0.11,6.65 \pm 0.18, \%$, and $1.99 \pm$ $0.029 \%$ ) in all groups these results agreed with those recoded by Reece and Frazier (1991) who stated that Small chickens are detectable by 4-6 days of age. Some birds ceased to grow and remained about $200 \mathrm{gm}$ at 6-8 weeks of age (Runts) such chickens are usually culled. And AbdulAziz (1995) who stated that $10 \%$ of birds were affected between the 2nd and the 5th week of life experiencing retarded growth.

On the other hand the effect of IBO virus infection in 20 day old chickens showed mortality rate ranged from 10-30\%, These findings were similar to those mentioned by Kurade et al. (2000).; and Giasuddin et al. (2005). Chicks died post inoculation showed depression anorexia, ruffled feather, watery yellowish- white diarrhea, body weight variation, trembling, and death, These finding similar to Islam and Samad (2003); and Hafz et al. (2003). Gross lesions was dehydrated emaciated carcass, haemorrhagic spots on thigh and breast muscle, swollen pale or congested kidneys. Bursa of fabricius was enlarged or atrophied in some cases. These findings agreed with EI-Batrawi (1990) and Islam and Samad (2003). Examination of infected chicken performance (BW, FI, FCR)after 28 days old (one week post IBOV infection) revealed significant decrease in body gain (BG) specially intraocular infected groups $(822.37 \pm 9.16 \mathrm{gm})$ when compared with $11 \mathrm{M}$ and orally infected groups and control $(842.35 \pm 5.11,857.2 \pm 7.6$, and 1207.85 $\pm 11.6 \mathrm{gm}$ respectively). While no changes in feed intake in all groups. Significant decrease in FCR observed in all groups when compared with control group, FCR was $2.28 \pm 0.018,2.23 \pm 0.023,2.34 \pm 0.018, \%$, and 1.58 \pm $0.02 \%$ ) in all groups. While after 35 day old (two week post IBOV infection) revealed significant decrease in body gain (BG) specially $1 / \mathrm{M}$ infected groups $(895.25 \pm 12.98 \mathrm{gm})$ when compared with orally and intraocular infected groups and control $(905.94 \pm 30.07,934.16 \pm 11.68 \mathrm{gm}$ 
and $1544.28 \pm 17.43 \mathrm{gm}$ respectively). While no changes in feed intake in all groups. Significant decrease in FCR observed in all groups when compared with control group, FCR was $3.55 \pm 0.058,3.42 \pm 0.047,3.4 \pm$ $0.04, \%$ and $1.99 \pm 0.023 \%$ ) in all groups these results agreed with Okoye and Aba Adulugba (1998); and Paula et al (2004) they mentioned that birds survived the diseases lost weight from 1190 to $1320 \mathrm{~g}$ (Group I) than those broilers which did not have Gumboro (Group II; 1585-1620 g). Thus, there is a significant variation in body weight of Gumboro affected broilers due to existing and imposed vaccination program.

Histopathological changes after IBOV infection the bursa of fabricius revealed lymphoid necrosis practically in the medullary zone and replaced by eosinophlic necrotic debris or become atrophied and shrunken together with vesicle formation in its covering epithelium. Lymphocytes had pyknosis and karyorrhexis of their nuclei with hyperplasia of reticulo endothelial cells. Intense heterephil in inter follicular tissues and within the cavities of some cystic follicles beside fibroplasia were common. Moreover, edema in interfolicular tissues and subepithelial with hyperemic capillaries were seen beside hyperplasia of epithelial covering. These findings are similar to Khafagy et al. (1991) and Paul et al. (2003).

Histopathological changes after ReoVirus infection revealed inter glandular edema accompanied by leukocytic aggregates mainly heterophils and lymphocytes proventriculaur Submucosa. In the other cases, disseminated leukocytic infiltration accompanied with degenerated and necrotic changes in the compound glands of the submucosa were evident. The mucosa was edematous and infiltrated with leukocytes. These findings agreed with Goodwin et al. (1996) who mentioned that deep non purlulent necrotizing proventriculitis (accompanied by

Interstitial leukocytic infiltration mainly mild lymphocytes were seen among pancreatic acini these finding similar to Riddell and Derow (1985), Reece and Frazier (1991). Also Focal hepatic necrosis with hemorrhages were common. Perivascular edema in some portal areas together with degenerated and necrotic changes in the hepatic were common in other cases. Glavits et al. (1984) observed dilated liver sinusoids and swollen endothelial cells. There was accumulation of heterophil granulocytes, monocytes, kupffer cells and there were signs of degeneration. Multinucleated giant cells were also demonstrated among the hepatocytes. 
It is concluded that Reo virus and IBDV infections are highly serious diseases inducing severe decrease in body weight leading to high economic losses at the end of fattening period, where the decrease in body weight ranged from $(66.370 \%$, and $40-42 \%$ in Reo and IBDV respectively. From the previous results it is clear that vaccination against Reo virus and IBDV especially in breeder hens considered an utmost need to avoid the economic losses

\section{REFERENCES}

Abdul-Aziz, T.A. (1995): Field outbreak of infectious stunting syndrome in broiler chickens in Jordan. Tropical-Animal-HealthandProduction, 1995, 27: 173-174.

Bancrefr, J.D. and Stevens, A. (1996): theory and practice of histological technique. 4th $\mathrm{Ed}$.churchuill. Livingsstone, Edinburgh. London Melbaurne and New York.

Bayoumie, H.A.A. (2004): Studies on Reovirus infection in chicken. PH.D thesis in poult.dis. fact. Vet. Med. Zagazig

Chooi, K.F. and Chulan, U. (1985): Broi ler ranting / stunting syndrome in Malaysia. Vet. Rec. 350: 354

Decaesstecker, M.G.; Chariler, G. and Meulemans, G. (1986): .Significance of Parvo viruses, Entro-like viruses and Reoviruses in the aetiology of the chicken mal absorption syndrome Avian path.15: 769-782

EI-Batrawi, A.M. (1990): Studies on severe outbreaks of infectious bursal disease. The natural and experimental disease. Proceedings 2nd Scientific Conference of the Egyptian Veterinary Poultry Association, 12-14 March, Cairo: 239-252.

Giambrone, J.J. (2002a): Infection bursal disease virus: an old foe changes its face again. Educational Development Magazine, Feb pp: 10

Giambrone, J.J. (2002b): Working group 3: vaccination" passive protection and vaccination (current and future possibility) in the presence of maternally derived antibody" third meeting Pulawy, Poland, keynote lecture.

Giasuddin, M.; Alam, J.; Islam, M.R; Taimur, M.J.F.A. and Rahman, M.M. (2005): Epidemiological investigation of infectious bursal disease in Bangladesh. Indian. J. Poult. Sci. 2005; 40: 99-101.

Glavits, R.; Molnar, E.; Ratz, F.; Saghy, E.Q.; Fehervarie, T. and Meder, 
M. (1984): pathological studies in chicken embryos and day old chickens experimentally infected with avian Reoviruses. Acta. Vet. Hungurie 32: 33-37

Goodwin, M.A.; Dekish, M.; Latimer, K.S. and Fletcher, O.J. (1985): Quantitation of intestinal D-xylose absorption in normal broilers and in broilers with bale bird syndrome. Avian Dis 24: 630-639.

Goodwin, M.A.; Hafner, S.; Bounous, D.I..; Latimar, K.S.; Player, E.C.; Niagro, F.D.; Campagnali, R.P. and Brown, J. (1996): Viral proventriculitis in chickens. Avian path, 25: 369-379.

Hafez,H.M.; Prusas, C. and Raue, R. (2003): Very virulent infectious bursal disease virus (vvIBDV) in vaccinated broiler flock: course of the disease, identification and characterisation of isolated strain. Archiv-fur-Geflugelkunde. 2003; 67: 2-5

Huff, G.R; Huff, W.E.; Balog, J.M.; Rath, N.C. and Zheng, Q. (1997): Studies of infectious proventriculitis proc. $32^{\text {Dd }}$ National meeting on poultry health \& processing October 15-17, Sheraton Ocean City, Ocean City Maryland .. pp 39-43

Islam, M.T. and Samad, M. (2003): Outbreaks of infectious bursal disease in vaccinated and unvaccinated commercial cockerel farms in Bangladesh. Bangladesh J. Vet. Med 1: 21-24.

Khafagy, A.K.; Assia, M. EI-SaWY; Kouwenhoven, B.; Vielitz, E.; Ismail, A.A.; Sultan, H.A. and EIGohary, A.E. (1991): Very virulent infectious bursal disease. Vet. Med. J. Giza, 39; 299-317.

Kouwenhoven, B.; Vertommen, M. and Goren, E. (1988): Investigation into the role of reovirus in the malabsorption syndrome. Avian Path. 17: 879-892.

Kurade, N.P.; Bhat, T.K. and Jithendran, K.P. (2000): Occurrence of infectious bursal disease and its pathology in the birds of Himachal Pradesh. Indian J. Vete. Path. 24: 133-134

Mcferran, J.B.; Me Nulty, M.S.; Me Cracken, R.M. and Creene, J. (1998): Enteritis \& associated problems in: disease prevention and control in poultry production Edited by Hugnerpford, T.G; Sydney, University Press

Me Nulty. M.S.; Connor, T.J.; Me Neitly, F. and Me Ferran, J.B. (1990): Biological characterization of an avian enetroviruses like viruses. Avian Path. 19: 75-87

Okoye, J.O.A. and Aba Adulugba, E.P. (1998): Comparative study of the resistance or susceptibility of local Nigerian and exotic ch 
ickens to infectious bursal disease. Avian path. 27: 168-174

Page, R.K.; Fletcher, O.J.; Rowland, G.N.; Grandy, D. and Vilegas, P. (1982): Malabsorption syndrome in broiler chickens. Avian Dis. 26: 618-624

Paul, B.K; Das, S.K; Badhy, S.C.; Amin, M.R.; Amin, KM.R. and Banik, S.C. (2003): Effect of existing and imposed vaccination on body weight against Gumboro in broilers under farm conditions. Int J. Poult. Sci. 3: 655-657.

Paula, B.C.; de., Yokosawa, J.; Coutinho, M.D.B.; Silva, P.L.; Ferraz, R.A.; Oliveira, T.F.M. and Queiroz, D.A.O. (2004): Identification and molecular characterization of the infectious bursal disease virus (IBDV) from an outbreak in a broiler flock in midwestem Brazil Brazilian-Joumal-of-Microbiology. 35: 352-358

Reece, R.L.; Hooper, P.T.; Tate, S.H.; Beddome, V.D.; Forsyth, W.M.; Scott, P.C. and Barr, D.A. (1984): Field, clinical and pathological observations of a runting and stunting syndrome in broilers. Vet. Rec. 115: 483-485.

Reece, R.L (1997): Infectious stunting syndrome. In : Poultry Diseases. $4^{\text {th }}$ edition pp. $375-388$ edited by Jordan, F.TW.; Pattison, M. Saunders W.B. Co, Ltd., London, Philadelphia, Toronto, Sydney, Tokyo.

Reece, R.L. and Frazier, J.A. (1991): Infectious stunting syndrome of chickens in Great Britain: ReId and experimental studieies Avian Path. 19: 723.

Reed, L.J and Muench, H. (1938): A simple method for estimating fifty percent end points. Am. J. Hyg, 27: 496

Riddell, C. and Derow, D.C. (1985): infectious stunting and pancreatic fibrosis in broiler chickens in Saskatchewan. Avian Dis.29: 107-115

Rosenberger, J.K.; Sterner, F.J.; Botts, S.; Lee, P.K. and Margolin, A. (1989): In Vitro and In Vivo characterization of avian Reoviruses. I. Pathogenicity and antigenic relatedness of several avian Reovirus isolates. Avian Dis. 33: 535-544.

Senne, DA. (2008): Viruses propagation eggs. pp. 204. In, isolation, identification and characterization of avian pathogen. 5 th Ed.Edited by Zavala L D, Swayne, DE, Glissone JR,Peasson JE MW, Woolcock PR.published AAAP 953 collage station Road aschens GA 30602-4875.

Skeelses, J.k.; Bayyari, G.R.; Newberry, L.A.; Wilson, M.A.; Huff, W.E.; 
Beasley, J.N.; Clark, F.; Whitfill, C.E and Haddad, E. (1995): The involvement of infectious bursal disease Virus as a cause of proventriculi tis in chickens ,46 th North Central Disease conference Minneapolis, $\mathrm{M}$.

Tamhane, A.C. and Dunlop, D.D. (2000): Statistics and data analysis from elementary to intermediate. Upper saddle River, USA.

Thayer, S.G. and Beard, C.W. (2008): Serological procedure. Pp222 In ,isolation, identification and characterization of avian pathogen.5 th Ed.Edited by Zavala L D, Swayne, DE, Glissone JR, Peasson JE MW, Woolcock PR.published AAAP 953 collage station Road aschens GA 30602-4875.

Wood, G.W.; Mackenzie, G.; Dagless, M.D.; Pearson, D.B. and Delissen, $G$. (1997): Re emergence ofa stunting syndrome in broiler chicken.Vet. Rec: 463.

Zekarias, B.; songserm, T.; Post, J.; Kok, G.L.; Pol, J.M.A.; Engel, B.; and Ter-Huurne, A.A.H.M. (2002): Development of organs and intestinal mucosa leukocytes in four broiler lines that differ in susceptibility to malabsorption syndrome Pou ItryScience. 2002, $81: 9,1283 ; 27$.

Zeleke, A.; Gelaye, E.; Sori, T.; Ayelet, G.; Sirak, A. and Zekarias, B. (2005): Investigation on infectious bursal disease outbreak in Debre Zeit, Ethiopia. Inter. J. Poult. Sci. 2005; 4: 504-506. 